Journal of Science
http://dergipark.gov.tr/gujs

\title{
Phylogenetic Analysis of Origanum vulgare and Its Antioxidant and Antimicrobial Activity
}

\author{
Arzu OZGEN 1* (D) , Nurcihan TAN ERKOC $^{1}$ (D) Omer Faruk TASTAN $^{2}$ (D) , Funda PEHLEVAN ${ }^{1}$ \\ ${ }^{l}$ Vocational School of Health Services, Istanbul Gelisim University, Istanbul, Turkey \\ ${ }^{2}$ Micro S Biyoteknoloji A.S. Istanbul, Turkey
}

Highlights

- We carried out the molecular characterization and the phylogenetic analysis of thyme.

- We analyzed the antioxidant activity of the thyme using DPPH method.

-We investigated the antibacterial activity of the thyme using disc diffusion and MIC methods.

- We showed that $O$. vulgare isolate SRY61 has high biological activity compared to the literature.

Article Info

Received:11 June 2020

Accepted:03 Nov 2020

\section{Keywords}

Origanum vulgare

Internal transcribed

Spacer

Antioxidant activity

Antibacterial activity

\begin{abstract}
Our country is home to many endemic plant species including medicinal, aromatic and spice. One of these species is thyme plant used both in daily life and for medical purposes. One of the most popular methods of phylogenetic classification of plants is the internal transcribed spacer (ITS) region which locates between the ITS1 and ITS2 regions that highly conserved. In this paper, a thyme species was used, which grows naturally in Sultan Murat Sarıkaya High-plateau in eastern Black Sea Region (Turkey) and phylogenetic analysis of oregano plant was carried out and antioxidant and antibacterial activity was investigated. The assessment of the antioxidant activity of the plant was researched using DPPH method using plant excretes prepared at various time intervals. The antibacterial activity of plant was studied by using disc diffusion and minimum inhibitory concentration (MIC) methods against Gram (+) and Gram (-) bacteria. The phylogenetic analysis was performed by obtaining the genomic DNA of the plant by the analysis of the specific DNA sequences used in the species identification, and the species of the plant was identified as Origanum vulgare and was identified as MH174928.1 (Origanum vulgare isolate SRY61) from Gen Bank. O. vulgare showed a high rate of antioxidant properties and showed antibacterial effect in accordance with the literature.
\end{abstract}

\section{INTRODUCTION}

A species of the genus Origanum, a member of the Lamiaceae family, O. vulgare is a perennial plant growing widely in Europe, North Africa, America and Asia [1]. It is found in areas that are dry and sunny, low humid and streamside [2]. The plant is known for its potent antibacterial, fungicidal and antiviral properties, as well as its nematicidal, antimutagenic and spasmolytic properties [3-5]. It contains various phenolics compounds [6].

It is estimated that there are 300000 plant species on earth. [7]. Today, phylogenetic analysis has become part of the systematics. Studies at the molecular level suggest that the analysis of ribosomal DNA (rDNA) ITS sites can be used to study a genus, species, and even populations because of the evolution of these regions [8]. ITS regions are powerful phylogenetic markers that show species differences at species level [9]. Nuclear ribosomal RNA genes (nrDNA) targeted at molecular classification studies are found in tandemly repeated and several loci $[10,11]$ and nrDNA spacer regions are useful tools to species level in plant systematics.

Reactive oxygen species (ROS) and lipid peroxides are formed as the normal products of aerobic metabolism, but oxidative stress occurs when they are produced at high rates or if their elimination is 
reduced. In this process, ROSs attack and damage macromolecules [12-14]. Some of the products in the structure of the plant are rich in phytochemicals and have strong and diverse biological and pharmacological properties $[15,16]$. Nowadays, plants with these properties draw interest because they are sources of natural antioxidants and prevent the negative effects of ROS and free radicals which cause cell destruction [17]. Studies showing the antioxidant activity of oregano, which is one of these plants, mainly dedicate this property to carvacrol and timole [18].

The use of antibiotics, which caused significant reduction of many infectious diseases since their discovery, has become highly risky due to the resistance of microorganisms in which they are effective nowadays and even in 2011, WHO used "Antimicrobial resistance: no action today, no cure tomorrow". This process has led the world of science to produce natural products of plant origin, which contain very few side effects and contain antimicrobial components [19-22]. Especially in some African and Asian countries, the majority of the population benefit from herbal medicinal products in primary health care [23]. Plants oils and extracts with antimicrobial properties have been implicated in many applications, such as pharmaceuticals, alternative medicine and natural treatments, in the preservation of raw and processed foods [24].

It is important to standardize the herbal extracts with protective and therapeutic properties and to protect these plants. It is seen as an important advantage that these naturally sourced compounds reduce the resistance development mechanism in bacteria and target more than one bacterium at the same time. Moreover, some herbal-derived antimicrobials have been accepted as "Generally Recognized as Safe" (GRAS), with a "greener" [25]. Thyme and oregano plants contain bioactive molecules such as thymol and carvacrol in their structures. These molecules, called monoterpenes, have antibacterial effects on bacteria [26]. Carvacrol and thymol have the capacity to break down the outer membrane of $G(-)$ bacteria and disrupt the integrity of the cell membrane structure of $\mathrm{G}(+)$ bacteria [27]. ATP synthesis is inhibited because of the change of osmotic pressure due to ion concentration due to the disruption of the membrane structure, followed by cell death [28]. Therefore, thymol and carvacrol are widely used as antibacterial in medicine, veterinary medicine and cosmetic industry [6,29].

In this study, the phylogenetic analysis of the oregano, which grows naturally in Sarkkaya Plateau in the eastern Black Sea Region of Turkey with an altitude of 2100 meters, with the ITS nucleotide sequence was carried out and its antioxidant and antibacterial effects were investigated.

\section{MATERIAL METHOD}

\subsection{Plant Material}

The oregano, which grows naturally in Sultan Murat Sarkkaya Plateau located at $40^{\circ} 38^{\prime} 37.2^{\prime \prime} \mathrm{N}$ $40^{\circ} 09^{\prime} 03.3^{\prime \prime} \mathrm{E}$ with an altitude of 2100 meters, was collected in August 2017. The oregano was dried in an area with no direct sunlight and light air flow.

\subsection{Bacterial Strains}

The bacterial strains used in this study were obtained from Prof. İkbal Agah İNCE. In antibacterial activity assays, eight bacteria were used (see Table 3).

\subsection{Ethanol Extraction Procedure}

$200 \mathrm{mg}$ of dried and powdered plant leaves were weighed and kept for $10 \mathrm{~min}$ in $5 \mathrm{~mL}$ ethanol (absolute) in ultrasonic bath (Bandelin sonorex, RK $100 \mathrm{H}$ ) at various intervals $(2,4,6,8$, and 10 minutes) and at 35 $\mathrm{kHz}$ and $37^{\circ} \mathrm{C}$. Samples were centrifuged at $6000 \mathrm{xg}$ for 15 minutes. The supernatant phase was taken and passed through Whatmann paper No: 1 . It was put in incubator at $37^{\circ} \mathrm{C}$ for complete removal of ethanol. 


\subsection{Total Genomic DNA Isolation of The Oregano}

The oregano leaves were disinfected with $70 \%$ ethanol for 3 min to remove the microorganisms that they may contain on their surfaces. The plant leaves were passed through the sterile purified water and then subjected to the bead-beating process of the ZymoBIOMICS DNA Miniprep Kit (D4303). The following steps were carried out according to the defined procedure in the kit. The concentration of the obtained genomic DNA was measured with nanodrop.

\subsection{Amplification of Ribosomal RNA (rRNA) Internal Transcribed Spacer (ITS) Regions and Sequence Analysis}

ITS DNA regions of oregano were amplified by polymerase chain reaction (PCR) using ITS specific universal primers (Table 1). The $50 \mu \mathrm{L}$ of PCR reaction contained $0.2 \mathrm{mM}$ dNTP mix, $0.2 \mu \mathrm{M}$ of each primer, $10 \mathrm{ng}$ DNA, $5 \mathrm{X}$ Phusion HF buffer (contains $7.5 \mathrm{mM} \mathrm{MgCl}_{2}$ which provides $1.5 \mathrm{mM} \mathrm{MgCl}_{2}$ in final concentration) and $0.02 \mathrm{U} / \mu \mathrm{L}$ of Phusion DNA polymerase (Thermo Scientific) in the BIO-RAD T100Thermal Cycler. The PCR conditions were followings; an initial denaturation and enzyme activation step of 30 seconds at $98^{\circ} \mathrm{C}$ was followed by 35 cycles amplification at the following conditions; 10 seconds at $98{ }^{\circ} \mathrm{C}, 30$ seconds $53{ }^{\circ} \mathrm{C}$ and 40 seconds $72{ }^{\circ} \mathrm{C}$ and 10 minutes extension at $72{ }^{\circ} \mathrm{C}$ completed the protocol. The PCR product was separated in $1 \%$ agarose gel at $80 \mathrm{~V}$ voltage for $45 \mathrm{~min}$ and visualized on BIO-RAD ChemiDoc MP Imaging System. ITS DNA region fragment was excised and purified using the Zymo Gel DNA Recovery Kit (D4007) and purified ITS DNA amplicon concentration was measured using nanodrop and sequenced at the Macrogen Company. The nucleotide sequence data was searched with the GenBank. The ITS DNA sequence of oregano was registered to the GenBank and the accession number was acquired.

Table 1. Primers used in this study

\begin{tabular}{|l|l|}
\hline Primers & Sequences $\left(\mathbf{5}{ }^{\prime}-\mathbf{3}\right.$ ') \\
\hline ITS1 Fw & TCCGTAGGTGAACCTGCGG \\
\hline ITS2 Rv & GCTGCGTTCTTCATCGATGC \\
\hline ITS3 Fw & GCATCGATGAAGAACGCAGC \\
\hline ITS4 Rv & TCCTCCGCTTATTGATATGC \\
\hline ITS5 Fw & GGAAGTAAAAGTCGTAACAAGG \\
\hline
\end{tabular}

\subsection{Phylogenetic Analysis}

For the phylogenetic analysis of Origanum vulgare isolate SRY61, the ITS1, partial sequence; 5.8S rRNA gene and ITS2, complete sequence, and large subunit rRNA gene, partial sequence of 31 species that are closely related to Origanum vulgare isolate SRY61 according to GenBank was used. Phylogenetic analyses were achieved by using the Maximum Likelihood method and Tamura-Nei model and conducted in MEGA $X$ [30-32]. The names and countries of the species and the access numbers of the sequences taken from GenBank used in the dendrogram are shown in Table 2.

Table 2. The names, countries and the access numbers of the species of Origanum and Micromeria as an outgroup

\begin{tabular}{|l|l|l|l|l|l|}
\hline Genus & Species & Country & $\begin{array}{l}\text { Partial } \\
\text { Sequence } \\
(\mathbf{b p )}\end{array}$ & $\begin{array}{l}\text { GenBank } \\
\text { Accession } \\
\text { Number }\end{array}$ & References \\
\hline Origanum & $\begin{array}{l}\text { Origanum } \\
\text { vulgare SRY61 }\end{array}$ & Turkey:Trabzon & 668 & MH174928.1 & Unpublished \\
\hline Origanum & $\begin{array}{l}\text { Origanum } \\
\text { vulgare } \text { 076 }\end{array}$ & cult-USA & 704 & DQ667243.1 & {$[33]$} \\
\hline Origanum & $\begin{array}{l}\text { Origanum } \\
\text { vulgare subsp. } \\
\text { virens LO414 }\end{array}$ & Morocco & 693 & MG434484.1 & Unpublished \\
\hline
\end{tabular}




\begin{tabular}{|c|c|c|c|c|c|}
\hline Origanum & $\begin{array}{l}\text { Origanum } \\
\text { vulgare subsp. } \\
\text { virens } \mathrm{LO} 413\end{array}$ & Morocco & 693 & MG434485.1 & Unpublished \\
\hline Origanum & $\begin{array}{l}\text { Origanum grosii } \\
\text { LO407 }\end{array}$ & Morocco & 693 & MG434481.1 & Unpublished \\
\hline Origanum & $\begin{array}{l}\text { Origanum } \\
\text { elongatum } \\
\text { LO366 }\end{array}$ & Morocco & 695 & MG434473.1 & Unpublished \\
\hline Origanum & $\begin{array}{l}\text { Origanum onites } \\
\text { LR421 }\end{array}$ & Morocco & 692 & MG434483.1 & Unpublished \\
\hline Origanum & $\begin{array}{l}\text { Origanum } \\
\text { compactum } \\
\text { LO365 }\end{array}$ & Morocco & 693 & MG434472.1 & Unpublished \\
\hline Origanum & $\begin{array}{l}\text { Origanum } \\
\text { syriacum } \\
\text { RNG:H50 }\end{array}$ & Lebanon & 643 & JX163016.1 & Unpublished \\
\hline Origanum & $\begin{array}{l}\text { Origanum } \\
\text { majorana } \\
\text { SR562 }\end{array}$ & Malta: Mosta & 643 & JX162816.1 & Unpublished \\
\hline Origanum & $\begin{array}{l}\text { Origanum } \\
\text { vulgare } 3131\end{array}$ & $\begin{array}{l}\text { Germany: } \\
\text { Bavaria }\end{array}$ & 612 & GU381469.1 & [34] \\
\hline Origanum & $\begin{array}{l}\text { Origanum } \\
\text { syriacum } \\
\text { RNG:H50 }\end{array}$ & Lebanon & 643 & JX163019.1 & Unpublished \\
\hline Origanum & $\begin{array}{l}\text { Origanum } \\
\text { syriacum }\end{array}$ & Lebanon & 643 & JX163018.1 & Unpublished \\
\hline Origanum & $\begin{array}{l}\text { Origanum } \\
\text { vulgare voucher } \\
\text { B. Drew } 77\end{array}$ & USA & 693 & JQ669127.1 & [35] \\
\hline Origanum & $\begin{array}{l}\text { Origanum } \\
\text { syriacum } \\
\text { RNG:H50 }\end{array}$ & Lebanon & 643 & JX163012.1 & Unpublished \\
\hline Origanum & $\begin{array}{l}\text { Origanum onites } \\
\text { SR777 }\end{array}$ & Turkey: Antalya & 643 & JX162979.1 & Unpublished \\
\hline Origanum & $\begin{array}{l}\text { Origanum grosii } \\
\text { LO393 }\end{array}$ & Morocco & 693 & MG434478.1 & Unpublished \\
\hline Origanum & $\begin{array}{l}\text { Origanum } \\
\text { majorana } \\
\text { SR562 }\end{array}$ & Malta: Mosta & 643 & JX162818.1 & Unpublished \\
\hline Origanum & $\begin{array}{l}\text { Origanum } \\
\text { majorana } 10659\end{array}$ & Turkey: Icel & 643 & JX162775.1 & Unpublished \\
\hline Origanum & $\begin{array}{l}\text { Origanum onites } \\
\text { SR777 }\end{array}$ & Turkey: Antalya & 642 & JX162974.1 & Unpublished \\
\hline Origanum & $\begin{array}{l}\text { Origanum grosii } \\
\text { LO384 }\end{array}$ & Morocco & 693 & MG434479.1 & Unpublished \\
\hline Origanum & $\begin{array}{l}\text { Origanum } \\
\text { majorana } \\
\text { SR725 }\end{array}$ & Turkey: Anamur & 642 & JX162867.1 & Unpublished \\
\hline Origanum & $\begin{array}{l}\text { Origanum } \\
\text { majorana } \\
\text { SR558 }\end{array}$ & Turkey: Antalya & 643 & JX162856.1 & Unpublished \\
\hline Origanum & $\begin{array}{l}\text { Origanum } \\
\text { majorana } \\
\text { GAZI:H137 }\end{array}$ & Turkey: Akseki & 643 & JX162789.1 & Unpublished \\
\hline
\end{tabular}




\begin{tabular}{|l|l|l|l|l|l|}
\hline Origanum & $\begin{array}{l}\text { Origanum } \\
\text { majorana 10659 }\end{array}$ & Turkey: Icel & 643 & JX162788.1 & Unpublished \\
\hline Origanum & $\begin{array}{l}\text { Origanum } \\
\text { syriacum } \\
\text { RNG:H50 }\end{array}$ & Lebanon & 644 & JX163021.1 & Unpublished \\
\hline Origanum & $\begin{array}{l}\text { Origanum } \\
\text { majorana } \\
\text { SR1054 }\end{array}$ & Cyprus: Galia & 642 & JX162938.1 & Unpublished \\
\hline Origanum & $\begin{array}{l}\text { Origanum } \\
\text { majorana } \\
\text { SR725 }\end{array}$ & Turkey: Anamur & 643 & JX162862.1 & Unpublished \\
\hline Origanum & $\begin{array}{l}\text { Origanum } \\
\text { syriacum }\end{array}$ & Lebanon & 643 & JX163020.1 & Unpublished \\
\hline Origanum & $\begin{array}{l}\text { Origanum } \\
\text { syriacum }\end{array}$ & Lebanon & 643 & JX163015.1 & Unpublished \\
\hline Origanum & Origanum onites & Turkey: Antalya & 642 & JX162980.1 & Unpublished \\
\hline Origanum & $\begin{array}{l}\text { Origanum onites } \\
\text { SR777 }\end{array}$ & Turkey: Antalya & 642 & JX162977.1 & Unpublished \\
\hline Micromeria & $\begin{array}{l}\text { Micromeria } \\
\text { hyssopifolia }\end{array}$ & USA & 646 & AY227142.1 & Unpublished \\
\hline
\end{tabular}

\subsection{DPPH Radical-Scavenging Assay}

DPPH is one kind of the compound that has a proton free radical with a characteristic absorption at $517 \mathrm{~nm}$ [36]. The antioxidant activity of the oregano was assessed according to 1,1-diphenyl-2-picryl-hydrazil (DPPH) radical-scavenging assay using the method of Brand-Williams, 1995 [37]. $20 \mathrm{mg} / \mathrm{L}$ of the DPPH solution was prepared to be dissolved in ethanol. In the following step, the serial dilutions of the plant extract were prepared as $100,250,500,750$ and $1000 \mu \mathrm{g} / \mathrm{mL} .0 .75 \mathrm{~mL}$ of each plant dilutions were added on $1.5 \mathrm{~mL}$ of the DPPH solution. This mixture was incubated in a dark place in the room temperature for 30 minutes. The absorbance of the mixture was measured at $517 \mathrm{~nm}$. Ethanol was used as the blank and $100,250,500,750,1000 \mu \mathrm{g} / \mathrm{mL}$ concentrations of the Butylated hydroxyanisole (BHA), butylated hydroxytoluene (BHT) and ascorbic acid (AA) solutions were used as the standard antioxidants.

Antioxidant activity of oregano was calculated as:

DPPH Scavenging Effect $(\%)=\left[\left(\mathrm{A}_{\text {blank }}-\mathrm{A}_{\text {sample }}\right) / \mathrm{A}_{\text {blank }}\right] \times 100$.

The experiments were carried out in triplicates. The 50\% inhibition (IC50) value of the oregano extract was determined using AAT Bioquest Program [38].

\subsection{The Antimicrobial Activity}

The antibacterial activities of the oregano extract obtained by ethanol extraction were determined according to literature $[39,40]$. The oregano extract was dissolved in the DMSO to a final concentration of $30 \mathrm{mg} / \mathrm{mL}$. Eight bacterial species were grown in Luria-Bertani (LB) broth medium at $37^{\circ} \mathrm{C}$ for 16 hours at $200 \mathrm{rpm}$ in the dry air incubator. The liquid cultures were used in order to get $10^{8} \mathrm{CFU} / \mathrm{mL}$ bacteria [41]. $100 \mu \mathrm{L}$ of the bacteria suspensions were inoculated on the LB agar with the help of a steril L-spreader. The sterile discs (Whatmann No:1, $6 \mathrm{~mm}$ in diameter) were placed on the petri dishes. Then, the disks impregnated with the oregano extracts $(300 \mu \mathrm{g} / \mathrm{disc})$. Appropriate antibiotic disks were used as positive controls for each bacterial strain. For the negative control, the disks impregnated with DMSO were used. Bacteria were incubated at $37^{\circ} \mathrm{C}$ for 24 hours and the results of the diameters of inhibition zones were measured in millimeters. The experiments were repeated triplicates.

The MIC of oregano extract against bacteria was studied by broth micro dilution assay using 96-well cell culture plates [42]. $10^{8} \mathrm{CFU} / \mathrm{mL}$ of bacteria grown in broth culture for 12 hours were prepared as 
suspensions. The plant extract was dissolved in 10\% DMSO to a concentration of $500 \mu \mathrm{g} / \mathrm{mL}$. Into the each well of a 96-well plate, $95 \mu \mathrm{L}$ of LB broth and serial dilutions of plant extracts (from $500 \mu \mathrm{g} / \mathrm{mL}$ to 7.8125 $\mu \mathrm{g} / \mathrm{mL}$ ) were placed and $5 \mu \mathrm{L}$ of bacteria cultures were added. $195 \mu \mathrm{L}$ of LB broth agar and $5 \mu \mathrm{L}$ of bacteria were used as the negative control. For the positive control, the standard antibiotics were used. The 96-well plate was put on a shaker at $300 \mathrm{rpm}$ for 20 minutes and incubated at $37^{\circ} \mathrm{C}$ for 24 hours. Microbial growth was measured at $600 \mathrm{~nm}$ using the nanodrop. The study was repeated twice. MIC was defined as the lowest concentration that inhibits the bacterial growth.

\section{THE RESEARCH FINDINGS AND DISCUSSION}

\subsection{Molecular Identification}

Studies in the field of plant identification in the past few years have been conducted to determine the nuclear ribosomal RNA genes (nrDNA), DNA of mitochondria and chloroplast of plant taxonomy and phylogeny [43]. Especially spacer regions of nrDNA provides important information from plant to generic levels in plant systematics [44]. In addition, it is an important reason to design PCR primers suitable for these regions and make it easily in PCR process.

Plants are also found in two different consecutive repeat groups, the first $5 \mathrm{~S}$ and the second $18 \mathrm{~S}-5.8 \mathrm{~S}-26 \mathrm{~S}$, and the $18 \mathrm{~S}-5.8 \mathrm{~S}-26 \mathrm{~S}$ is used more for plant phylogeny and taxonomy. While the length of the ITS regions amplified using universal primers is approximately $700 \mathrm{bp}$ in angiosperms [43], it can be between 1500 and $3700 \mathrm{bp}$ in gymnosperms [45].

In this study, ITS1 sequence was amplified with ITS1 and ITS2 primer and PCR product of $335 \mathrm{bp}$ length was obtained, ITS2 sequence was amplified with ITS 3 and ITS4 primer and PCR product of 420 bp length was obtained, complete ITS sequence was amplified with ITS4 and ITS5 primer and PCR product of 745 bp length was obtained (Figure 1). The analyzed nrDNA length is $668 \mathrm{bp}$, because the complete ITS sequence PCR product was analyzed without cloning. Sanger dideoxy sequencing method was used in sequence analysis. The nrDNA nucleotide sequences obtained as a result of sequencing were determined to be $O$. vulgare at $99 \%$ similarity level compared with different $O$. vulgare species (Accesion number: MH645777.1, Accesion number: MG434484.1, Accesion number: MG434485.1) from NCBI GenBank and the accession number MH174928.1 (Origanum vulgare isolate SRY61) was taken from the gene bank.

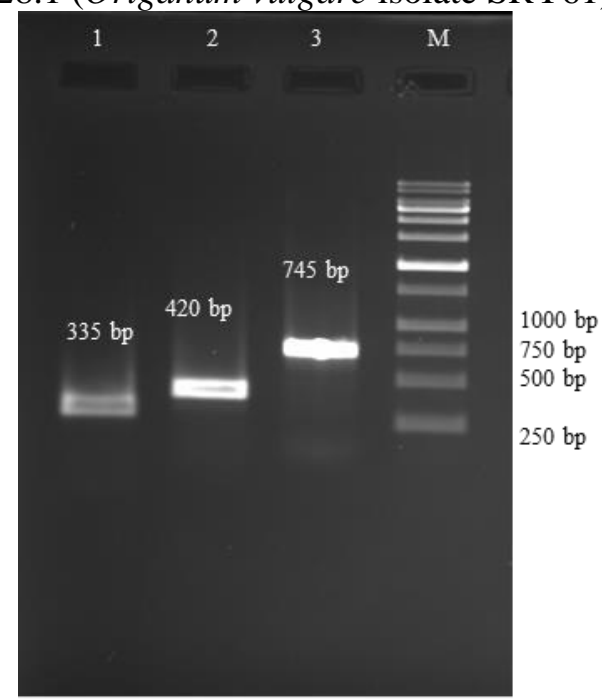

Figure 1. ITS regions of O. vulgare amplified by PCR. $1 \%$ agarose gel electrophoresis; Well $4(M)$ DNA ladder (SiZer-1000 DNA Marker iNtRON Biotechnology)

Based on $O$. vulgare's nrDNA ITS regions, the degree of relationship between species was determined using MEGA 10.8.1 (Molecular Evolutionary Genetics Analysis) phylogenetic tree program [46]. The evolutionary history was concluded by using the Maximum Likelihood method and Tamura-Nei model [30]. Evolutionary analyses were conducted in MEGA X [31,32]. Phylogenetic analysis grouped the 
Origanum vulgare isolate SRY61 (Turkey, MH174928.1) with Origanum elongatum (Morocco, MG434473.1), Origanum compactum (Morocco, MG434472.1), Origanum grosii (Morocco, MG434481.1) and Origanum vulgare (Germany: Bavaria GU381469.1) in a phylogenetic clade. Micromeria hyssopifolia was used as the outgroup in the phylogenetic tree drawing based on the region of approximately 570-704 bp (Figure 2). It is determined that $O$. vulgare, whose molecular identification was made according to the phylogenetic tree, is in close relationship with other species in the gene bank.

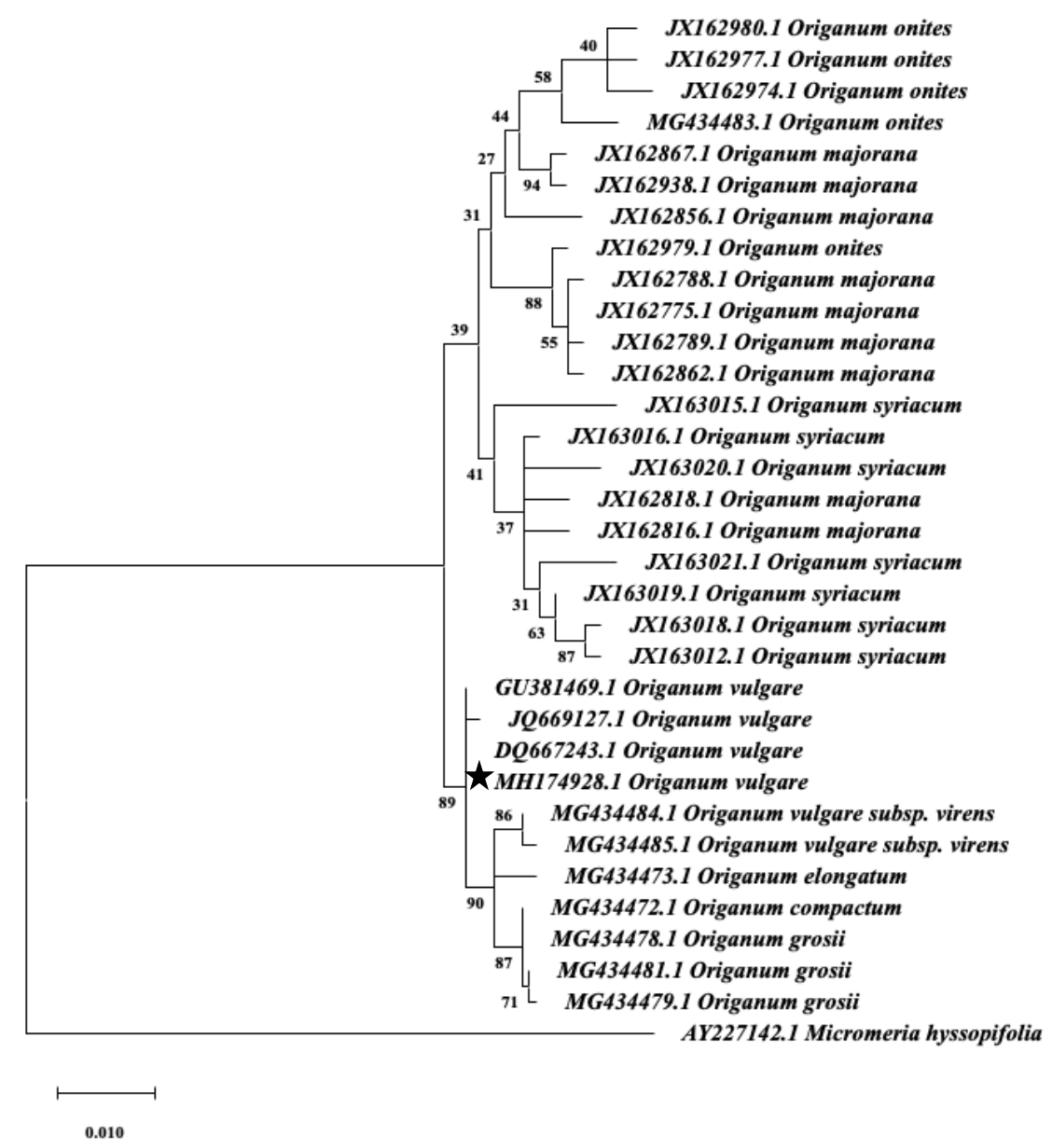

Figure 2. Molecular phylogenetic relationships of the Origanum species. Micromeria hyssopifolia (AY227142.1) was used as the outgroup

\subsection{Antioxidant Activity}

Oxidative stress is defined as disruption of the balance between oxidants and antioxidants in the process of detoxifying reactive oxygen species in biological systems [47]. All organisms have cellular defense systems to overcome oxidative stress. Free radicals react with important organic molecules such as lipids, DNA and proteins, and damage these molecules which may result in mutagenesis and carcinogenesis [48].

In recent years, interest and research have been increasing in alternative solutions that closely concern the food industry as well as human health and prevent food spoilage in the food industry or are protective and at the same time natural. Reasons of this include oxidation and microbial pathogen-induced poisoning cases and major economic losses caused by food degradation [49].

The plants under the biotic interactions and the abiotic conditions during their development (ontogenesis) 
[50] face a situation that significantly affects metabolism, development and yield. This is considered as stress in the plants and excessive ROS and reactive nitrogen species (RNS) are produced. In response to this increased reactive stress, in other words, to toxic effects, the plants produce antioxidants which are enzymatic Superoxide dismutase (SOD), catalase (CAT), glutathione peroxidase (GPx), and glutathione reductase (GR) [51] and non-enzymatic secondary metabolites such as glutathione, proline, carotenoids, phenolic acids, flavonoids, vitamin $\mathrm{C}$, vitamin $\mathrm{E}$, phenolic acids, terpenes and tannins. These produced molecules act as free radical scavengers, reducing agents and metal chelators [52-54].

Today, there are techniques to assess the antioxidant activity of many plant samples [54]. In studies conducted under the laboratory conditions, plants show strong antioxidant activity due to various compounds found in their structures [55]. HAT-based methods are based on an antioxidant clearing free radicals through hydrogen donation and converting them into stable compounds. Single-electron-transfer (SET)-based methods measure an antioxidant's ability to transfer an electron to reduce any compound, including metals, carbonyls, and free radicals [56,57].

A number of studies have showed differences in the biological activities of extracts prepared using different extraction methods. Ultrasonic assisted solvent extraction (UAE) is a process that uses high intensity, high frequency sound waves and solvents [58]. The standard methods such as soxhlet used for antioxidant extractions are disadvantageous in terms of time, use of large amounts of toxic solvent and cost. UAE has been shown to be a more effective and environmentally safe way of extracting natural antioxidants [59].

$\mathrm{IC}_{50}$ value of DPPH \% scavenging activity at the concentrations of $100,250,500,750,1000 \mu \mathrm{g} / \mathrm{mL}$ was calculated using AAT Bioquest Program as for the 6th minute at various intervals (2, 4, 6, 8, and 10 minutes) prepared from plant extracts $0.0513 \pm 0.002 \mathrm{mg} / \mathrm{mL}$. IC I $_{50}$ value for BHA, BHT, and AA solution $(100,250$, $500,750,1000 \mu \mathrm{g} / \mathrm{mL}$ ) was calculated as $0.041 \pm 0.002,0.34 \pm 0.002$, and $0.23 \pm 0.006 \mathrm{mg} / \mathrm{mL}$, respectively [38].

The free radical scavenging activity of extracts are between $84.2-93.36 \%$ at a concentration of $250 \mu \mathrm{g} / \mathrm{mL}$ for the 6th minute. It is great importance that these values are very close to the standards values. Positive DPPH test suggested that the extracts were good free radical scavenging. Figure 3 showed thyme extracts had good DPPH scavenging activity with standards and had higher DPPH scavenging activity with the decreasing concentration.

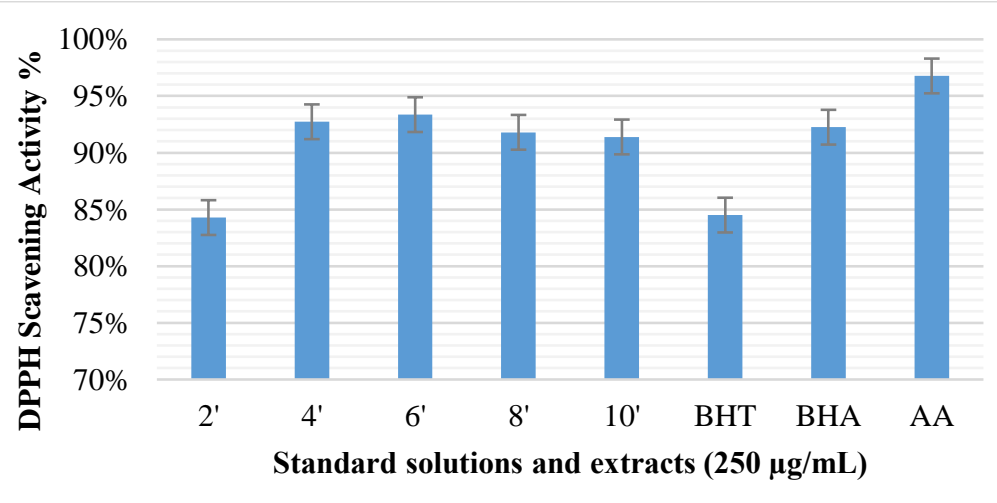

Figure 3. The DPPH scavenging activities of the standard solutions (BHA, BHT and AA) and ethanolic oregano extract

It is clear from results Figure 4 that the highest scavenging activity was viewed 6th extractions minute. 


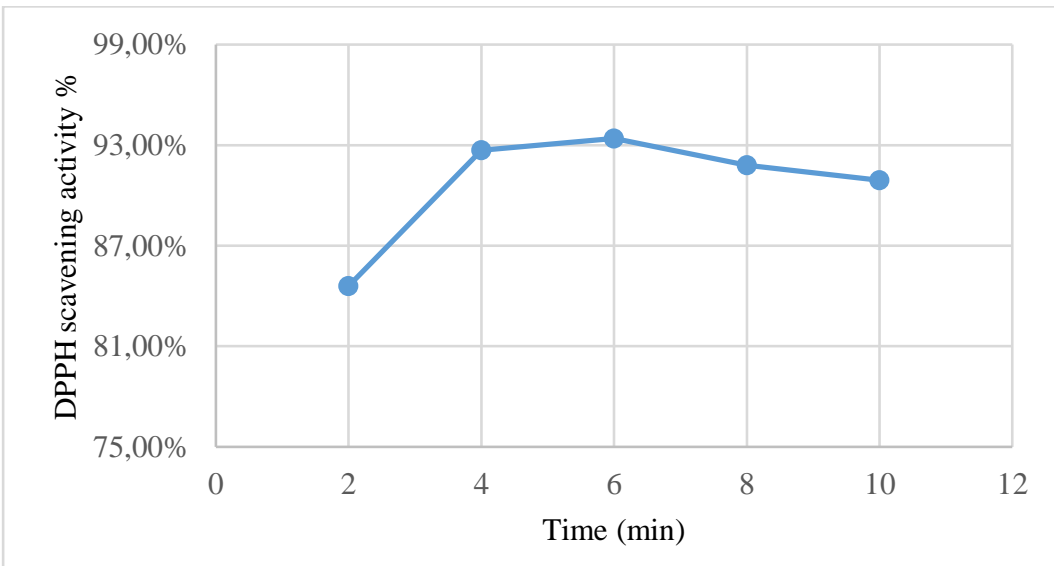

Figure 4. Time related DPPH scavening activity \% of the ethanolic oregano extract $(250 \mu \mathrm{g} / \mathrm{mL})$

Thus, high radical scavenging effect was recorded for thyme extract in as little as 6 minutes. Major components such as carvacrol and thymol contained by the oregano plant have scavenging activity of free radicals, transition-metal-chelating [60] and single-oxygen-quenching capacity. Many of the free radical scavengers, such as carvacrol and thymol, convert hydrogen radicals into more stable non-radical products [61].

In the previous studies using hydrodistillation extraction method, $O$. vulgare extracts were shown to have high radical scavenging activity. Mechergui et al. in 2010, they examined $O$. vulgare L. subsp. glandulosum methanol extract method in different concentrations $(12.5$ to $500 \mathrm{mg} / \mathrm{mL})$ and determined that $\mathrm{IC}_{50}$ value was 59 to $80 \mathrm{mg} / \mathrm{mL}$ [62]. Kaurinovic et al. in 2011, they found the $\mathrm{IC}_{50}$ value of $O$. vulgare methanol extract in different concentrations $(2.5$ to $50 \mu \mathrm{g} / \mathrm{mL})$ and determined that $\mathrm{IC}_{50}$ value was $68.17 \mu \mathrm{g} / \mathrm{mL}$ [63]. The ethanol extract in different concentrations $(0.10$ to $3.20 \mathrm{mg} / \mathrm{mL})$ derived from $O$. vulgare $\mathrm{L}$. was determined that $\mathrm{IC}_{50}$ value $0.332 \mathrm{mg} / \mathrm{mL}$ by Han et al. in 2017 [64]. Stanojević et al. in 2016, they showed the $\mathrm{IC}_{50}$ value of $O$. vulgare ethanol extract in different concentrations $(0.098$ to $12.5 \mathrm{mg} / \mathrm{mL}) 0.761$ to $0.326 \mathrm{mg} / \mathrm{mL}$ [65]. Our study compared with the studies in the literature, the results obtained are consistent and it was determined that our oregano extract at lower concentrations has better DPPH radical scavenging activity than some previous papers. It was concluded that these results are due to the ultrasonic assisted solvent extraction method, which prevents possible loss in the content of foods used in the study and provides high efficiency. Therefore, the ultrasonic assisted solvent extraction method, that is used in our study, is more efficient than hydrodistillation extraction method.

\subsection{Antibacterial Activity}

In this study, we investigated the antibacterial activity of $O$. vulgare obtained by ethanol extraction against eight microorganisms by the disc diffusion and MIC assay. The results are given in Table 3. Based on the results, oregano extract formed a zone of inhibition between $9.5 \mathrm{~mm}$ and $11.5 \mathrm{~mm}$ on bacteria. In the MIC study, the MIC value of the oregano extract on bacteria species was determined as $15.625 \mu \mathrm{g} / \mathrm{mL}$ and $7.8125 \mu \mathrm{g} / \mathrm{mL}$.

Table 3. Antibacterial activity of $O$. vulgare extract against the bacterial strains assayed

\begin{tabular}{|c|c|c|c|c|}
\hline \multirow[b]{2}{*}{ Pathogens } & \multicolumn{2}{|c|}{ Plant Extract (EtOH) } & \multicolumn{2}{|l|}{ Antibiotics } \\
\hline & $\begin{array}{l}\text { Disc } \\
\text { diffusion }^{\mathrm{a}} \\
(300 \mu \mathrm{g} / \text { disc })\end{array}$ & $\begin{array}{l}\text { Minimal } \\
\text { Inhibition } \\
\text { Concentration } \\
(\mu \mathrm{g} / \mathrm{mL})\end{array}$ & $\begin{array}{l}\text { Disc } \\
\text { diffusion }^{b}\end{array}$ & $\begin{array}{l}\text { Minimal } \\
\text { Inhibition } \\
\text { Concentration } \\
(\mu \mathrm{g} / \mathrm{mL})\end{array}$ \\
\hline S. aureus ATCC 25923 & $10 \mathrm{~mm}$ & 7.8125 & $\begin{array}{ll}33 & \mathrm{~mm} \\
(\mathrm{AM}) & \end{array}$ & $2(\mathrm{VA})$ \\
\hline $\begin{array}{l}\text { S. epidermidis ATCC } \\
12228\end{array}$ & $10.5 \mathrm{~mm}$ & 15.625 & $\begin{array}{ll}30 & \mathrm{~mm} \\
\text { (VA) }\end{array}$ & $2(\mathrm{VA})$ \\
\hline
\end{tabular}




\begin{tabular}{|c|c|c|c|c|}
\hline $\begin{array}{l}P . \quad \text { aeruginosa } A T C C \\
27853\end{array}$ & $9.5 \mathrm{~mm}$ & 15.625 & $\begin{array}{ll}20 & \mathrm{~mm} \\
(\mathrm{AK}) & \end{array}$ & $8(\mathrm{AK})$ \\
\hline $\begin{array}{l}\text { K. pneumoniae ATCC } \\
700603\end{array}$ & $10 \mathrm{~mm}$ & 15.625 & $\begin{array}{l}20 \mathrm{~mm} \\
(\mathrm{FOX})\end{array}$ & $8(\mathrm{AMC})$ \\
\hline E. coli ATCC 25922 & $10.5 \mathrm{~mm}$ & 15.625 & $\begin{array}{l}20 \mathrm{~mm} \\
(\mathrm{AMC})\end{array}$ & $8(\mathrm{AMC})$ \\
\hline P. mirabilis ATCC 27853 & $10 \mathrm{~mm}$ & 15.625 & $\begin{array}{l}20 \mathrm{~mm} \\
(\mathrm{FOX})\end{array}$ & $8(\mathrm{AMC})$ \\
\hline $\begin{array}{l}\text { S. Typhimurium ATCC } \\
14028\end{array}$ & $11.5 \mathrm{~mm}$ & 15.625 & $\begin{array}{l}23 \mathrm{~mm} \\
(\mathrm{SXT})\end{array}$ & $2(\mathrm{SXT})$ \\
\hline $\begin{array}{l}\text { A. baumannii ATCC BAA } \\
747\end{array}$ & $10.5 \mathrm{~mm}$ & 15.625 & $\begin{array}{ll}24 & \mathrm{~mm} \\
(\mathrm{AM}) & \end{array}$ & $2(\mathrm{SXT})$ \\
\hline
\end{tabular}

${ }^{\mathrm{a}}$ Inhibition Diameter $(\mathrm{mm}){ }^{2}$ Including Disk Diameter of $6.0 \mathrm{~mm}^{2}$

b AM: ampicillin $(10 \mu \mathrm{g} / \mathrm{mL})$; VA: vancomycin $(30 \mu \mathrm{g} / \mathrm{mL})$; AK: amikacin $(30 \mu \mathrm{g} / \mathrm{mL})$; FOX: cefoxitin $(30 \mu \mathrm{g} / \mathrm{mL})$; AMC: amoxicillin-clavulanate $(20 / 10 \mu \mathrm{g} / \mathrm{mL})$; SXT: trimethoprim-sulphamethoxazole $(1.25 / 23.75 \mu \mathrm{g} / \mathrm{mL})$

Plant species belonging to Lamiacea family are very rich in antimicrobial content [66]. Having a strong antibacterial activity, $O$. vulgare gets this feature from its compounds such as phenolic monoterpens, carvacrol and thymol [67]. Many existing studies have generally examined the antibacterial effect of $O$. vulgare essential oils (EO). Since EO extract contains carvacrol and thymol more concentrated than oregano plant extract, their toxic effects on bacterial cells will be higher [68].

Santoyo et al. in 2005, they made a solution of oregano extract with a concentration of $40 \mathrm{mg} / \mathrm{mL}$ in a volume of $200 \mu \mathrm{L}$, using disc diffusion method, 19.2-20.2 $\mathrm{mm}$ for E. coli, 19.6-20.2 $\mathrm{mm}$ for B. subtilis and $19 \mathrm{~mm}$ for $P$. aeruginosa and they have observed inhibition zones of up to 8-21.8 $\mathrm{mm}$. They determined the minimum bactericidal concentration (MBC) $2.05-2.25 \mathrm{mg} / \mathrm{mL}$ for $E$. coli, $1.95-2.25 \mathrm{mg} / \mathrm{mL}$ for $B$. subtilis and $1.75-2.12 \mathrm{mg} / \mathrm{mL}$ for $P$. aeruginosa [69].

In another study conducted by the company Brđanin et al. in 2015, they found the MIC value of oregano plant for cyclohexane, dichloromethane, methanol extracts 62.5 to $125 \mu \mathrm{g} / \mathrm{mL}$ for $S$. aureus (ATCC 25923), 62.5 to $125 \mu \mathrm{g} / \mathrm{mL}$ for S. epidermidis (ATCC 12228). $125 \mu \mathrm{g} / \mathrm{mL}$ for E. coli (ATCC 25922), $125 \mu \mathrm{g} / \mathrm{mL}$ for K. pneumoniae (NCIMB 9111), $125 \mu \mathrm{g} / \mathrm{mL}$ for P. aeruginosa (ATCC 27853) and 62.5 to $125 \mu \mathrm{g} / \mathrm{mL}$ for S. typhimurium [70].

In a study conducted by Coccimiglio et al. in 2016, they determined the MIC value by the ethanolic extracts of the oregano plant as $25 \mu \mathrm{g} / \mathrm{mL}$ for $P$. aeruginosa $25619,25 \mu \mathrm{g} / \mathrm{mL}$ for $E$. coli $25922,12.5 \mu \mathrm{g} / \mathrm{mL}$ for E. coli $700973,12.5 \mu \mathrm{g} / \mathrm{mL}$ for A. baumannii 19606 and $25 \mu \mathrm{g} / \mathrm{mL}$ for S. aureus 29213 [15]. In this study, quite good antibacterial activity was observed with the extract obtained by the extraction of the oregano plant with ethanol extraction compared to other studies.

\section{CONCLUSION}

In this paper, the plant obtained from Trabzon Sultan Murat Sarıkaya Plateau in eastern Black Sea Region has been determined as $O$. vulgare according to phylogenetic analysis and MH174928.1 (Origanum vulgare isolate SRY61) has been obtained from Gen Bank as the Accesion number. The antioxidant activity of the plant was found to be quite high compared to the standard solutions. In addition, the fact that its antibacterial activity is effective in all eight bacterial species has shown that this plant can be safely used in the preservation of raw and processed foods.

\section{ACKNOWLEDGEMENTS}

This work was supported by Istanbul Gelisim University, The Scientific Research Projects Application And Research Center, BAPUM with Project No.: YUP-080518-AÖ. We would like to thank the Acrbadem Mehmet Ali Aydınlar University. 


\section{CONFLICTS OF INTEREST}

No conflict of interest was declared by the authors.

\section{REFERENCES}

[1] Elezi, F., Plaku, F., Ibraliu, A., Stefkov, G., Karapandzova, M., Kulevanova, S., Aliu, S., "Genetic variation of oregano (Origanum vulgare L.) for etheric oil in Albania", Agricultural Sciences, 4(09): 449, (2013).

[2] Temel, M., Tokur, S., "Origanum vulgare L. (Lamiaceae) üç alttürünün korolojisi ve habitat özellikleri”, Journal of the Institute of Science \& Technology of Dumlupinar University/Dumlupinar Üniversitesi Fen Bilimleri Enstitüsü Dergisi, 33: 53-64, (2014).

[3] Lemhadri, A., Zeggwagh, N. A., Maghrani, M., Jouad, H., Eddouks, M., "Anti-hyperglycaemic activity of the aqueous extract of Origanum vulgare growing wild in Tafilalet region", Journal of ethnopharmacology, 92(2-3): 251-256, (2004).

[4] Lukas, B., Novak, J., "The complete chloroplast genome of Origanum vulgare L. (Lamiaceae)", Gene, 528(2): 163-169, (2013).

[5] Baricevic, D., Bartol, T., "The biological/pharmacological activity of the Origanum genus", Oregano, the genera Origanum and Lippia, New York: Taylor \& Francis Inc, pp. 177-201, (2002).

[6] Rao, G. V., Mukhopadhyay, T., Annamalai, T., Radhakrishnan, N., Sahoo, M. R., "Chemical constituents and biological studies of Origanum vulgare Linn", Pharmacognosy Research, 3(2): 143, (2011).

[7] Li, X., Yang, Y., Henry, R. J., Rossetto, M., Wang, Y., Chen, S., "Plant DNA barcoding: from gene to genome", Biological Reviews, 90(1): 157-166, (2015).

[8] White, T. J., Bruns, T., Lee, S. J. W. T., Taylor, J., "Amplification and direct sequencing of fungal ribosomal RNA genes for phylogenetics", PCR Protocols: A Guide to Methods and Applications, 18(1): 315-322, (1990).

[9] Alvarez, I., Wendel, J. F., "Ribosomal ITS sequences and plant phylogenetic inference”, Molecular Phylogenetics and Evolution, 29: 417-434, (2003).

[10] Hamby, R. K., Zimmer, E. A., "Ribosomal RNA as a phylogenetic tool in plant systematics", In: Molecular systematics of plants, Springer, Boston, MA., pp. 50-91, (1992).

[11] Hillis, D. M., Dixon, M. T., "Ribosomal DNA: molecular evolution and phylogenetic inference", The Quarterly Review of Biology, 66(4): 411-453, (1991).

[12] Jomova, K., Valko, M., "Advances in metal-induced oxidative stress and human disease", Toxicology, 283(2-3): 65-87, (2011).

[13] Suntres, Z. E., "Role of antioxidants in paraquat toxicity", Toxicology, 180(1): 65-77, (2002).

[14] Suntres, Z. E., "Liposomal antioxidants for protection against oxidant-induced damage", Journal of Toxicology, 2011: 152474, (2011). 
[15] Coccimiglio, J., Alipour, M., Jiang, Z. H., Gottardo, C., Suntres, Z., “Antioxidant, antibacterial, and cytotoxic activities of the ethanolic Origanum vulgare extract and its major constituents", Oxidative Medicine and Cellular Longevity, 2016: 1404505, (2016).

[16] Verma, A. R., Vijayakumar, M., Rao, C. V., Mathela, C. S., "In vitro and in vivo antioxidant properties and DNA damage protective activity of green fruit of Ficus glomerata", Food and Chemical Toxicology, 48(2): 704-709, (2010).

[17] Abdul, Q. M., Shahzadi, S. K., Bashir, A., Munir, A., Shahzad, S., "Evaluation of phenolic compounds and antioxidant and antimicrobial activities of some common herbs", International Journal of Analytical Chemistry, 2017: 1-7, (2017).

[18] Can, B. K. H., "Biological and pharmacological activities of carvacrol and carvacrol bearing essential oils", Current Pharmaceutical Design, 14(29): 3106-3119, (2008).

[19] Gould, I. M., "The epidemiology of antibiotic resistance", International Journal of Antimicrobial Agents, 32: 2-9, (2008).

[20] Martínez, J. L., Rojo, F., Vila, J., “Are nonlethal targets useful for developing novel antimicrobials?”, Future Microbiology, 6(6): 605-607, (2011).

[21] Osbourn, A. E., "Preformed antimicrobial compounds and plant defense against fungal attack", The Plant Cell, 8(10): 1821, (1996).

[22] Nash, R. J., Kato, A., Yu, C. Y., Fleet, G. W., "Iminosugars as therapeutic agents: recent advances and promising trends", Future Medicinal Chemistry, 3(12): 1513-1521, (2011).

[23] Tagboto, S., Townson, S., "Antiparasitic properties of medicinal plants and other naturally occurring products", Advances in Parasitology, 50: 199-295, (2001).

[24] Savoia, D., "Plant-derived antimicrobial compounds: alternatives to antibiotics", Future Microbiology, 7(8): 979-990, (2012).

[25] Xi, Y., Sullivan, G. A., Jackson, A. L., Zhou, G. H., Sebranek, J. G., "Use of natural antimicrobials to improve the control of Listeria monocytogenes in a cured cooked meat model system", Meat Science, 88(3): 503-511, (2011).

[26] Martelli, G., Giacomini, D., "Antibacterial and antioxidant activities for natural and synthetic dualactive compounds", European Journal of Medicinal Chemistry, 158: 91-105, (2018).

[27] Lambert, R. J. W., Skandamis, P. N., Coote, P. J., Nychas, G. J., "A study of the minimum inhibitory concentration and mode of action of oregano essential oil, thymol and carvacrol", Journal of Applied Microbiology, 91(3): 453-462, (2001).

[28] Ultee, A., Bennik, M. H. J., Moezelaar, R. J. A. E. M., "The phenolic hydroxyl group of carvacrol is essential for action against the food-borne pathogen Bacillus cereus", Appl. Environ. Microbiol., 68(4): 1561-1568, (2002).

[29] Palaniappan, K., Holley, R. A., "Use of natural antimicrobials to increase antibiotic susceptibility of drug resistant bacteria", International Journal of Food Microbiology, 140(2-3): 164-168, (2010).

[30] Tamura, K., Nei, M., "Estimation of the number of nucleotide substitutions in the control region of mitochondrial DNA in humans and chimpanzees", Molecular Biology and Evolution, 10(3): 512-526, (1993). 
[31] Kumar, S., Stecher, G., Li, M., Knyaz, C., Tamura, K., "MEGA X: molecular evolutionary genetics analysis across computing platforms", Molecular Biology and Evolution, 35(6): 1547-1549, (2018).

[32] Stecher, G., Tamura, K., Kumar, S., "Molecular evolutionary genetics analysis (MEGA) for macOS", Molecular Biology and Evolution, 37(4): 1237-1239, (2020).

[33] Walker, J. B., Sytsma, K. J., "Staminal evolution in the genus Salvia (Lamiaceae): molecular phylogenetic evidence for multiple origins of the staminal lever", Annals of Botany, 100(2): 375-391, (2007).

[34] Bräuchler, C., Meimberg, H., Heubl, G., "Molecular phylogeny of Menthinae (Lamiaceae, Nepetoideae, Mentheae)-Taxonomy, biogeography and conflicts", Molecular Phylogenetics and Evolution, 55(2): 501-523, (2010).

[35] Drew, B. T., Sytsma, K. J., "Phylogenetics, biogeography, and staminal evolution in the tribe Mentheae (Lamiaceae)", American journal of botany, 99(5): 933-953, (2012).

[36] Tung, Y. T., Wu, J. H., Kuo, Y. H., Chang, S. T., “Antioxidant activities of natural phenolic compounds from Acacia confusa bark”, Bioresource Technology, 98(5): 1120-1123, (2007).

[37] Brand-Williams, W., Cuvelier, M. E., Berset, C., "Use of a free radical method to evaluate antioxidant activity”, Food Science and Technology-Lebensmittel Wissenschaft und Technologie, 28: 25-30, (1995).

[38] AAT Bioquest, Inc.,"Quest Graph $^{\mathrm{TM}}$ IC50 Calculator", $\quad$ Retrieved from https://www.aatbio.com/tools/ic50-calculator, (2020).

[39] Russell, A. D., Furr, J. R., "The antibacterial activity of a new chloroxylenol preparation containing ethylenediamine tetraacetic acid", Journal of Applied Bacteriology, 43(2): 253-260, (1977).

[40] Irobi, O. N., Moo-Young, M., Anderson, W. A., Daramola, S. O., "Antimicrobial activity of bark extracts of Bridelia ferruginea (Euphorbiaceae)", Journal of Ethnopharmacology, 43(3): 185-190, (1994).

[41] Clinical and Laboratory Standards Institute, "Methods for dilution antimicrobial susceptibility tests for bacteria that grow aerobically; approved standard", 9 th ed., CLSI document M07-A9, Wayne, 68, (2012).

[42] National Committee for Clinical Laboratory Standards, "Performance Standards for Antimicrobial Susceptibility Testing", 12 th ed., Informational Supplement M100-S12, NCCLS, Wayne, PA, (2002).

[43] Baldwin, B. G., Sanderson, M. J., Porter, J. M., Wojciechowski, M. F., Campbell, C. S., Donoghue, M. J., "The ITS region of nuclear ribosomal DNA: a valuable source of evidence on angiosperm phylogeny", Annals of the Missouri Botanical Garden, 82(2): 247-277, (1995).

[44] Poczai, P., Hyvönen, J., "Nuclear ribosomal spacer regions in plant phylogenetics: problems and prospects", Molecular Biology Reports, 37(4): 1897-1912, (2010).

[45] Álvarez, I., Wendel, J. F., "Ribosomal ITS sequences and plant phylogenetic inference”, Molecular Phylogenetics and Evolution, 29(3): 417-434, (2003).

[46] Stecher, G., Tamura, K., Kumar, S., "Molecular evolutionary genetics analysis (MEGA) for macOS", Molecular Biology and Evolution, 37(4): 1237-1239, (2020). 
[47] Commoner, B., Townsend, J., Pake, G. E., "Free radicals in biological materials", Nature, 174(4432): 689-691, (1954).

[48] Dupont, G. P., Huecksteadt, T. P., Marshall, B. C., Ryan, U. S., Michael, J. R., Hoidal, J. R., "Regulation of xanthine dehydrogenase and xanthine oxidase activity and gene expression in cultured rat pulmonary endothelial cells”, The Journal of Clinical İnvestigation, 89(1): 197-202, (1992).

[49] Rodriguez-Garcia, I., Silva-Espinoza, B. A., Ortega-Ramirez, L. A., Leyva, J. M., Siddiqui, M. W., Cruz-Valenzuela, M. R., Ayala-Zavala, J. F., "Oregano essential oil as an antimicrobial and antioxidant additive in food products", Critical Reviews in Food Science and Nutrition, 56(10): 1717-1727, (2016).

[50] Suzuki, N., Rivero, R. M., Shulaev, V., Blumwald, E., Mittler, R., "Abiotic and biotic stress combinations", New Phytologist, 203(1): 32-43, (2014).

[51] Chanda, S., Dave, R., "In vitro models for antioxidant activity evaluation and some medicinal plants possessing antioxidant properties: An overview", African Journal of Microbiology Research, 3(13): 981-996, (2009).

[52] Michalak, A., "Phenolic compounds and their antioxidant activity in plants growing under heavy metal stress", Polish Journal of Environmental Studies, 15(4): 523-30, (2006).

[53] Winkel-Shirley, B., "Biosynthesis of flavonoids and effects of stress", Current opinion in plant biology, 5(3): 218-223, (2002).

[54] Rivero, R. M., Ruiz, J. M., Garcıa, P. C., Lopez-Lefebre, L. R., Sánchez, E., Romero, L., "Resistance to cold and heat stress: accumulation of phenolic compounds in tomato and watermelon plants", Plant Science, 160(2): 315-321, (2001).

[55] Alam, M. N., Bristi, N. J., Rafiquzzaman, M., "Review on in vivo and in vitro methods evaluation of antioxidant activity", Saudi Pharmaceutical Journal, 21(2): 143-152, (2013).

[56] Karadag, A., Ozcelik, B., Saner, S., "Review of methods to determine antioxidant capacities", Food Analytical Methods, 2(1): 41-60, (2009).

[57] Prior, R. L., Wu, X., Schaich, K., "Standardized methods for the determination of antioxidant capacity and phenolics in foods and dietary supplements", Journal of Agricultural and Food Chemistry, 53(10): 4290-4302, (2005).

[58] Dhanani, T., Shah, S., Gajbhiye, N. A., Kumar, S., "Effect of extraction methods on yield, phytochemical constituents and antioxidant activity of Withania somnifera", Arabian Journal of Chemistry, 10: 1193-1199, (2017).

[59] Xu, D. P., Zhou, Y., Zheng, J., Li, S., Li, A. N., Li, H. B., "Optimization of ultrasound-assisted extraction of natural antioxidants from the flower of Jatropha integerrima by response surface methodology", Molecules, 21(1): 2-12, (2016).

[60] Shan, B., Cai, Y. Z., Sun, M., Corke, H., "Antioxidant capacity of 26 spice extracts and characterization of their phenolic constituents", Journal of Agricultural and Food Chemistry, 53(20): 7749-7759, (2005).

[61] Choe, E., Min, D. B., "Mechanisms and factors for edible oil oxidation", Comprehensive Reviews in Food Science and Food Safety, 5(4): 169-186, (2006). 
[62] Mechergui, K., Coelho, J. A., Serra, M. C., Lamine, S. B., Boukhchina, S., Khouja, M. L., "Essential oils of Origanum vulgare L. subsp. glandulosum (Desf.) Ietswaart from Tunisia: chemical composition and antioxidant activity", Journal of the Science of Food and Agriculture, 90(10): 1745-1749, (2010).

[63] Kaurinovic, B., Popovic, M., Vlaisavljevic, S., Trivic, S., "Antioxidant capacity of Ocimum basilicum L. and Origanum vulgare L. extracts", Molecules, 16(9): 7401-7414, (2011).

[64] Han, F., Ma, G. Q., Yang, M., Yan, L., Xiong, W., Shu, J. C., Xu, H. L., “Chemical composition and antioxidant activities of essential oils from different parts of the oregano", Journal of Zhejiang University-Science B, 18(1): 79-84, (2017).

[65] Stanojević, L. P., Stanojević, J. S., Cvetković, D. J., Ilić, D. P., “Antioxidant activity of oregano essential oil (Origanum vulgare L.)”, Biologica Nyssana, 7(2): 131-139, (2016).

[66] Burt, S. A., Reinders, R. D., "Antibacterial activity of selected plant essential oils against Escherichia coli O157: H7”, Letters in Applied Microbiology", 36(3): 162-167, (2003).

[67] Bakkali, F., Averbeck, S., Averbeck, D., Idaomar, M., "Biological effects of essential oils-a review", Food and Chemical Toxicology, 46(2): 446-475, (2008).

[68] De Vincenzi, M., Silano, M., Maialetti, F., Scazzocchio, B., "Constituents of aromatic plants: II. Estragole", Fitoterapia, 71(6): 725-729, (2000).

[69] Santoyo, S., Cavero, S., Jaime, L., Ibanez, E., Senorans, F. J., Reglero, G., "Supercritical carbon dioxide extraction of compounds with antimicrobial activity from Origanum vulgare L.: determination of optimal extraction parameters", Journal of Food Protection, 69(2): 369-375, (2006).

[70] Brđanin, S., Bogdanović, N., Kolundžić, M., Milenković, M., Golić, N., Kojić, M., Kundaković, T., "Antimicrobial activity of oregano (Origanum vulgare L.): And basil (Ocimum basilicum L.): Extracts", Advanced Technologies, 4(2): 5-10, (2015). 